\title{
ANALISIS MANAJEMEN LABA DAN KINERJA KEUANGAN PERUSAHAAN PENGAKUISISI SEBELUM DAN SESUDAH MERGER DAN AKUISISI YANG TERDAFTAR DI BURSA EFEK INDONESIA
}

Oleh:

\section{Desiana}

Desianaa0912@gmail.com

Institut Bisnis dan Keuangan Nitro Makassar

\begin{abstract}
Abstrak
The purpose of this study was to obtain empirical evidence of whether the acquirer conduct earnings management prior to the implementation of mergers and acquisitions. Also aims to determine changes in the acquirer's financial performance before and after mergers and acquisitions.

Earnings management by firms is to proxy discretionary accrual (DA). Then for the measurement of company performance measured by financial ratios include total asset turn over, net provit margin, and return on asset. The analysis was done by using independent sample t-test and paired sample test.

The results shows that there is an indication of earnings management done by taking over companies before mergers and acquisitions by utilizing income increasing accruals. Furthermore, the company's financial performance as measured by total asset turnover ratio has increased after the merger and acquisition, while net profit margin and return on assets has decreased after the mergers and acquisitions.
\end{abstract}

Keywords : merger, acquisition, earnings management, performance

\section{PENDAHULUAN}

Perkembangan zaman yang begitu pesat semakin mendorong pemilik/manajemen perusahaan untuk mengembangkan usahanya dengan strategi bisnis baik jangka pendek maupun jangka panjang. Salah satu caranya adalah dengan penggabungan beberapa usaha. Dengan penggabungan beberapa usaha, diharapkan perusahaan-perusahaan itu dapat meningkatkan pangsa pasar, diversifikasi usaha, atau meningkatkan integrasi vertikal dari aktivitas operasional yang ada dan sebagainya. 
Pada dasarnya penggabungan usaha merupakan bentuk penggabungan satu perusahaan dengan perusahaan lain dalam rangka mendapatkan pengendalian atas aktiva maupun operasional. Bentuk penggabungan usaha yang sering dilakukan dalam dua dekade terakhir ini adalah merger dan akuisisi di mana strategi ini dipandang sebagai salah satu cara untuk mencapai beberapa tujuan yang lebih bersifat ekonomis dan jangka panjang (Lani Dharmasetya dan Vonny Sulaimin,2009).

Menurut data statistik Bursa Efek Jakarta-berganti nama menjadi Bursa Efek Indonesia- antara tahun 1995-1997 (sebelum terjadinya krisis moneter pada Juli 1997), jumlah perusahaan yang go public tercatat kurang lebih sebanyak 259 perusahaan. Sebanyak 57 perusahaan yang melakukan penggabungan usaha. Pada pasca krisis moneter tahun 2000 sampai dengan pertengahan tahun 2008, penggabungan usaha dilakukan oleh lebih 40 perusahaan (Lani Dharmasetya dan Vonny Sulaimin,2009). Bentuk penggabungan usaha yang sering dilakukan dalam dua dekade terakhir ini adalah merger dan akuisisi di mana strategi ini dipandang sebagai salah satu cara untuk mencapai beberapa tujuan yang lebih bersifat ekonomis dan jangka panjang (Lani Dharmasetya dan Vonny Sulaimin,2009).

Merger dan akuisisi menjadi trend bisnis di tahun 1990-an di Amerika Serikat yang dimulai di tahun 1992. Sejak tahun 1992 perusahaan yang melakukan merger dan akuisisi terus meningkat, bahkan jika dibandingkan antara tahun 1996 dan 1995 peningkatan merger dan akuisisi meningkat hingga 67\% (Sotensen,2000). Demikian pula di Indonesia dengan adanya peraturan perundang-undangan yang mempermudah masuknya investor asing, merger dan akuisisi, maka pelaksanaan merger dan akuisisi meningkat (Saiful,2003).

Berdasarkan laporan yang diterbitkan KPMG (Klynveld Peat Marwick Goerdeler) International, yaitu salah satu perusahaan jasa profesional terbesar di dunia dan juga merupakan salah satu anggota The Big Four Auditors nilai transaksi merger dan akuisisi pada tahun 2007 
diperkirakan mencapai US\$3,79 triliun. Pada semester kedua tahun 2007 mencatat rekor baru dimana secara global transaksi merger mencapai US\$1,65 triliun atau meningkat 90\% dibanding periode yang sama pada tahun 2006. Hal ini menunjukkan masih tingginya aktivitas merger dan akuisisi di kalangan pelaku perusahaan (Lani Dharmasetya dan Vonny Sulaimin, 2009:2)

Dalam pelaksanaan merger dan akuisisi terdapat suatu kondisi yang mendukung adanya tindakan manajemen laba yang dilakukan oleh perusahaan pengakuisisi. Pada situasi perusahaan pengakuisisi ingin melakukan merger dan akusisi dengan cara pembayaran lewat saham, pihak manajemen perusahaan pengakuisisi cenderung akan berusaha untuk meningkatkan nilai laba perusahaannya. Tujuannya adalah selain ingin menunjukkan earnings power perusahaan agar dapat menarik minat perusahaan target untuk melakukan akuisisi juga untuk meningkatkan harga saham perusahaannya (Lani Dharmasetya dan Vonny Sulaimin, 2009:16)

Ada alasan mendasar mengapa manajer perusahaan melakukan manajemen laba. Harga pasar saham suatu perusahaan secara signifikan dipengaruhi oleh laba, risiko, dan spekulasi. Oleh sebab itu, perusahaan yang labanya selalu mengalami kenaikan dari periode ke periode secara konsisten akan mengakibatkan risiko perusahaan ini mengalami penurunan lebih besar dibandingkan prosentase kenaikan laba. Hal inilah yang mengakibatkan banyak perusahaan yang melakukan pengelolaan dan pengaturan laba sebagai salah satu upaya untuk mengurangi risiko.

Erickson dan Wang (1999) dalam Hastutik (2006) menyatakan bahwa kecenderungan adanya praktik manajemen laba menjelang merger dan akuisisi bertujuan untuk meningkatkan harga sahamnya sebelum stock merger agar dapat mengurangi biaya pembelian perusahaan target. Keputusan manajemen perusahaan yang memilih untuk melakukan manajemen laba dengan cara income increasing accruals akan membawa konsekuensi terhadap kinerja perusahaan yang akan mengalami suatu kenaikan pada periode sesudahnya.

Alasan perusahaan lebih tertarik memilih merger dan akuisisi sebagai strateginya daripada pertumbuhan internal adalah karena merger dan akuisisi dianggap jalan cepat untuk mewujudkan tujuan perusahaan di mana perusahaan tidak perlu memulai dari awal suatu bisnis baru. Merger dan akuisisi juga dianggap dapat menciptakan sinergi, yaitu nilai keseluruhan perusahaan setelah merger dan akuisisi yang lebih besar daripada penjumlahan nilai masing- masing perusahaan sebelum merger dan akuisisi. Selain itu merger dan akuisisi dapat memberikan banyak keuntungan bagi perusahaan antara lain peningkatan kemampuan dalam 
pemasaran, riset, skill manjerial, transfer teknologi, dan efisiensi berupa penurunan biaya produksi (Hitt,2002).

Perubahan-perubahan yang terjadi setelah perusahaan melakukan merger dan akuisisi biasanya akan tampak pada kinerja perusahaan dan penampilan finansialnya. Pasca merger dan akuisisi kondisi dan posisi keuangan perusahaan mengalami perubahan dan hal ini tercermin dalam laporan keuangan perusahaan yang melakukan merger dan akuisisi. Untuk menilai bagaimana keberhasilan merger dan akuisisi yang dilakukan, dapat dilihat dari kinerja perusahaan setelah melakukan merger dan akuisisi terutama kinerja keuangan baik bagi perusahaan pengakuisisi maupun perusahaan diakuisisi. Dasar logika dari pengukuran berdasar akuntansi adalah bahwa jika skala bertambah besar ditambah dengan sinergi yang dihasilkan dari gabungan aktivitasaktivitas yang simultan, maka laba perusahaan juga semakin meningkat sehingga kinerja perusahaan pasca merger dan akuisisi seharusnya semakin baik dibandingkan dengan sebelum merger dan akuisisi.

Penelitian-penelitian terdahulu telah membuktikan adanya manajemen laba dalam beberapa kasus. Rahman dan Bakar (2002) seperti yang dikutip oleh Kusuma dan Udiana Sari (2003) telah membuktikan adanya manajemen laba melalui discreationary accrual pada perusahaan pengakuisisi sebelum merger dan akuisisi di Malaysia pada tahun sebelum akuisisi. Sementara Erickson dan Wang (1999) dalam Hastutik (2006) menunjukkan bahwa perusahaan pengakuisisi melakukan manajemen laba pada periode sebelum merger dan mengidentifikasi bahwa tingkat income increasing earnings management berhubungan positif dengan ukuran merger.

Kusuma dan Sari (2003) melakukan penelitian terhadap perusahaan yang melakukan kegiatan merger dan akuisisi di BEJ selama periode 1997-2002. Dalam penelitian tersebut diperoleh sebanyak 39 perusahaan sebagai sampel. Hasil penelitian menunjukkan bahwa dengan menggunakan model jones, pada periode sebelum merger dan akuisisi tidak terdapat indikasi adanya manajemen laba.

Di Inggris, Meeks (1997) dan Kumar (1984) dalam Hadiningsih (2007) meneliti pengaruh merger terhadap profitabilitas perusahaan yang melakukan merger. Penelitian itu membuktikan adanya penurunan profitabilitas yang signifikan setelah tiga tahun dan lima tahun dengan menggunakan laba operasi. Adanya perbedaan antara teori dengan hasil penelitian yang 
telah dilakukan menunjukkan bahwa ada hal yang terjadi yang memicu terjadinya penurunan kinerja perusahaan.

Payamta dan Sektiawan (2004) meneliti pengaruh merger dan akusisi terhadap kinerja perusahaan manufaktur selama 2 tahun sebelum dan 2 tahun sesudah merger dan akuisisi, yang diproksikan melalui return saham dan rasio keuangan. Hasil penelitan menunjukkan tidak adanya perbedaan kinerja yang signifikan untuk periode sebelum dan sesudah merger dan akuisisi baik dari return saham maupun rasio keuangan, penelitian ini dikonfirmasi oleh Sadi'yah (2005) dan Rosana (2005).

Hayati (2004) meneliti kasus akuisisi dengan memproksikan kinerja perusahaan melalui 10 rasio keuangan selama 2 tahun sebelum dan 2 tahun setelah akuisisi, hasilnya seluruh sampel menunjukkan penurunan kinerja keuangan setiap akhir tahun setelah merger dan akuisisi. Penelitian ini dikonfirmasi oleh Dewi (2004) dengan rasio keuangan yang berbeda.

Ravenscraft dan Sherer (1998) (dalam Wulandari, 2005) melakukan penelitian terhadap profitabilitas sebelum merger perusahaan target dan hasil operasinya setelah merger. Penelitiannya dilakukan terhadap perusahaan manufaktur di Amerika Serikat yang melakukan merger sebelum periode 1957-1977. Hipotesis yang dilakukan dalam penelitian mereka ada dua, yaitu bahwa perusahaan target tidak mendapat laba dan bahwa merger memperbaiki profitabilitasnya secara rata-rata. Profitabilitas sebelum merger di ukur dengan rasio laba operasi (sebelum bunga dan pajak serta biaya luar usaha) terhadap asset pada akhir periode, sedangkan profitabilitas setelah merger di ukur dengan tiga rasio yaitu: 1) rasio laba operasi, 2) rasio operasi laba penjualan, 3) rasio arus kas. Dari hipotesis pertama tidak dapat dibuktikan karena ketiadaan dukungan statistik, sedangkan pada hipotesis kedua disimpulkan bahwa tidak terdapat kenaikan yang signifikan terhadap profitabilitas setelah merger.

Kristiani dan Kwie (1999) meneliti bagaimana pengaruh akuisisi terhadap kinerja perusahaan akuisitor. Tujuan penelitiannya adalah untuk mengetahui kinerja perusahaan yang melakukan akuisisi, membandingkan kinerja akuisitor pada tahun sebelum terjadinya akuisisi dengan periode sebelumnya. Kinerja perusahaan akuisitor di ukur dengan rasio keuangan, yang meliputi: rasio likuiditas, rasio aktivitas, rasio leverage, rasio profitabilitas dan pergerakan harga saham setelah akuisisi. Ditemukan bahwa perusahaan akuisitor mengalami penurunan rasio likuiditas, aktivitas, profitabilitas, dan Indeks Harga Saham Gabungan mengalami kenaikan rasio leverage. 
Dari hasil-hasil penelitian diatas diperoleh adanya perbedaan hasil penelitian (research gap) yang dilakukan oleh para peneliti. Research gap yang telah dipaparkan diatas dapat dijadikan permasalahan dalam penelitian ini. Dengan melihat hasil penelitian tersebut, maka dapat dibuat pertanyaan penelitian sebagai berikut:

1. Apakah telah terjadi tindakan manajemen laba pada perusahaan pengakuisisi sebelum perusahaan tersebut melaksanakan kegiatan merger dan akuisisi?

2. Apakah terdapat perbedaan kinerja keuangan perusahaan pengakuisisi pada saat sebelum dan sesudah merger dan akuisisi?

Tujuan dalam penelitian ini adalah (1) membuktikan bahwa telah terjadi tindakan manajemen laba pada perusahaan pengakuisisi sebelum melakukan merger dan akuisisi. (2) membuktikan bahwa terdapat perbedaan kinerja keuangan perusahaan pengakuisisi sebelum dan sesudah merger dan akuisisi.

\section{TINJAUAN PUSTAKA}

Praktek manajemen laba dapat ditinjau dari dua perspekstif yang berbeda, yaitu perspektif etika bisnis dan teori akuntansi positif. Dari kacamata etika, dapat dianalisis sebab- sebab manajer melakukan manajemen laba, sementara itu dari kacamata teori akuntansi positif dapat dianalisis dan diidentifikasikan sebagai bentuk praktek manajemen laba yang dilakukan oleh manajer perusahaan. Esensi dari pendekatan moral atau etika adalah pencapai keseimbangan antara kepentingan individu (manajer) dengan kewajiban terhadap pihak-pihak yang terkait dengan perusahaan kepentingan principal dan akhirnya menjadi insentif bagi manajer untuk melakukan manajemen laba.

Perilaku manajemen laba dapat dijelaskan melalui Positive Accounting Theory dan Agency Theory. Watts dan Zimmerman (1986) dalam Halim dkk. (2005:119) mengusulkan tiga hipotesis yang dapat dijadikan dasar pemahaman tindakan manajemen laba yaitu sebagai berikut.

(1) Hipotesis Program Bonus (Bonus Plan Hypotesis). Hipotesis ini menyatakan bahwa manajer pada perusahaan yang menerapkan program bonus lebih cenderung untuk menggunakan metode atau prosedur-prosedur akuntansi yang akan menaikkan laba periode mendatang ke periode berjalan. (2) Hipotesis Perjanjian Utang (Debt Covenant Hypotesis). Hipotesis ini menyatakan bahwa perusahaan yang mempunyai rasio debt to equity besar atau menghadapi kesulitan utang, maka manajer perusahaan akan cenderung menggunakan metode akuntansi yang akan 
meningkatkan laba. (3) Hipotesis Kos Politis (Political Cost Hypotesis). Hipotesis ini menyatakan bahwa semakin besar biaya politik yang dihadapi suatu perusahaan maka manajer cenderung untuk menangguhkan laba berjalan ke masa yang akan datang. Biaya politik muncul sebagai akibat dari profitabilitas perusahaan yang tinggi dapat menarik perhatian media dan konsumen.

Manajemen laba adalah tindakan yang dilakukan oleh pihak manajemen dengan menaikkan atau menurunkan laba yang dilaporkan dari unit yang menjadi tanggung jawabnya yang tidak mempunyai hubungan dengan kenaikan atau penurunan profitabilitas dalam jangka panjang.

Perbedaan pemahaman terhadap manajemen laba mendorong semakin berkembangnya model empiris yang digunakan untuk mengidentifikasi akivitas rekayasa manajerial ini. Secara umum ada 3 kelompok model empiris manajemen laba yang diklasifikasikan atas dasar basis pengukuran yang digunakan, yaitu (Sulistyanto, 2008) :

a. Model berbasis akrual merupakan model yang menggunakan discretionary accruals sebagai proksi manajemen laba. Model manajemen laba ini dikembangkan oleh Healy (1985), De Angelo (1986), Jones (1991), serta Dechow, Sloan dan Sweeney (1995).

b. Model yang berbasis specific accruals, yaitu pendekatan yang menghitung akrual sebagai proksi manajemen laba dengan menggunakan item laporan keuangan tertentu dari industri tertentu pula. Model ini dikembangkan oleh Mc Nichols dan Wilson (1988) Petroni (1992), Beaver dan Engel (1996), Beneish (1997), serta Beaver dan Mc Nichols (1998).

c. Model distribution of earnings dikembangkan oleh Burgatler dan Dichey (1997), Degeorge, Patel, dan Zechauser (1999), serta Myers dan Skinner (1999).

Sejauh ini hanya model berbasis agregate accruals yang diterima secara umum sebagai model yang memberikan hasil paling kuat dalam mendeteksi manajemen laba. Model berbasis aggregate accruals yang digunakan adalah Modified Jones Model. Model tersebut dikembangkan oleh Dechow, Sloan, dan Sweeney (1995). Komponen total accruals dalam Modified Jones Model dapat dipisahkan menjadi 2, yaitu discretionary accruals dan non discretionary accruals. Discretionary accruals merupakan komponen total accruals yang berasal dari rekayasa manajerial dengan memanfaatkan kebebasan dan fleksibelitas dalam menentukan nilai estimasi pada metode akuntansi. Misalnya, kebebasan dalam menentukan estimasi nilai 
residu dalam penyusutan aktiva tetap dan estimasi nilai persentase piutang tidak tertagih. Sementara itu, non discretionary accruals merupakan komponen total accruals yang diperoleh secara alami dari pencatatan akuntansi dengan mengikuti standar akuntansi yang diterima secara umum (Sulistyanto, 2008)

Beberapa hal yang memotivasi seorang manajer untuk melakukan manajemen laba antara lain (1) bonus scheme, (2) debt covenant, (3) political motivation, (4) taxation motivation, (5) pergantian CEO, dan (6) initial public offering (Scott, 2000:352)

\section{Alasan bonus (bonus scheme)}

Adanya asimetri informasi mengenai keuangan perusahaan menyebabkan pihak manajemen dapat mengatur laba bersih untuk memaksimalkan bonus mereka.

2. Kontrak utang jangka panjang (debt covenant)

Semakin dekat perusahaan kepada kreditur, maka manajemen akan cenderung memilih prosedur yang dapat "memindahkan" laba periode mendatang ke periode berjalan. Hal ini bertujuan untuk mengurangi kemungkinan perusahaan mengalami kegagalan dalam pelunasan utang.

3. Motivasi politik (political motivation)

Perusahaan besar yang menguasai hajat hidup orang banyak akan cenderung menurunkan laba untuk mengurangi visibilitasnya, misalnya dengan menggunakan praktik atau prosedur akuntansi, khususnya selama periode dengan tingkat kemakmuran yang tinggi.

4. Motivasi pajak (taxation motivation)

Salah satu insentif yang dapat memicu manajer untuk melakukan rekayasa laba adalah untuk meminimalkan pajak atau total pajak yang harus dibayarkan perusahaan.

\section{Pergantian CEO (chief executive officer)}

Banyak motivasi yang muncul saat terjadi pergantian CEO. Salah satunya adalah pemaksimalan laba untuk meningkatkan bonus pada saat CEO mendekati masa pensiun.

6. IPO (initial public offering)

Perusahaan yang baru pertama kali menawarkan harga pasar, sehingga terdapat masalah bagaimana menetapkan nilai saham yang ditawarkan. Oleh karena itu, informasi laba bersih dapat digunakan sebagai sinyal kepada calon investor tentang nilai 
perusahaan, sehingga manajemen perusahaan yang akan go public cenderung melakukan manajemen laba untuk memperoleh harga lebih tinggi atas saham yang akan dijualnya.

Ikatan Akuntansi Indonesia (IAI) dalam pernyataan Standar Akuntansi Keuangan (PSAK No. 22, 2007) mendefinisikan penggabungan usaha sebagai bentuk penyatuan dua perusahaan atau lebih yang terpisah menjadi satu entitas ekonomi karena satu perusahaan menyatu dengan perusahaan lain ataupun memperoleh kendali atau kontrol atas aktiva dan operasi perusahaan lain.

Adapun beberapa teori yang dapat menjelaskan motivasi yang melatarbelakangi terjadinya suatu penggabungan usaha (Lani Dharmasetya dan Vonny Sulaimin, 2009) antara lain:

a. Teori efisiensi

Menurut teori ini, merger dapat meningkatkan efisiensi, karena akan menjadikan sinergi yang secara sederhana diartikan sebagai $2+2=5$, yaitu konsep dalam ilmu ekonomi yang mengatakan gabungan faktor-faktor yang komplementer akan menghasilkan keuntungan yang berlipat ganda.

b. Teori diversifikasi

Dengan memiliki bidang usaha yang beraneka ragam, maka suatu perusahaan dapat menjaga stabilitas pendapatannya.

c. Teori kekuatan pasar

Keinginan untuk meningkatkan pangsa pasar (market share) juga dapat menjadi salah satu motivasi terjadinya suatu merger. Penggabungan dua atau lebih perusahaan yang sebelumnya saling bersaing menjual produk yang sama, secara teoritis akan meningkatkan penguasaan pangsa pasar secara berlipat ganda.

d. Teori keuntungan pajak

Keuntungan di bidang perpajakan melalui pengurangan kewajiban pembayaran pajak dapat menjadi motivasi yang melatarbelakangi suatu merger.

e. Teori undervaluation

Penilaian harta yang lebih rendah dari harga sebenarnya pada suatu perusahaan akan mendorong minat perusahaan lainnya untuk menggabungkan perusahaan yang pertama ke dalam perusahaannya melalui merger. 


\section{f. Teori prestise}

Meskipun sulit untuk diterima secara logika, namun kenyataannya banyak merger dilakukan bukan karena motivasi ekonomis, melainkan karena motivasi ingin meningkatkan prestise.

Kinerja keuangan suatu perusahaan dapat diartikan sebagai prospek atau masa depan, pertumbuhan,dan potensi perkembangan yang baik bagi perusahaan. Informasi kinerja keuangan diperlukan untuk menilai perubahan potensial sumber daya ekonomi, yang mungkin dikendalikan di masa depan dan untuk memprediksi kapasitas produksi dari sumber daya yang ada (Barlian, 2003). Pimpinan perusahaan atau manajemen sangat berkepentingan terhadap laporan keuangan yang telah di analisis, karena hasil tersebut dapat dijadikan sebagai alat dalam pengambilan keputusan lebih lanjut untuk masa yang akan datang. Dengan menggunakan análisis rasio, berdasarkan data dari laporan keuangan, akan dapat diketahui hasil-hasil finansial yang telah di capai di waktuwaktu yang lalu, dapat diketahui kelemahan-kelemahan yang dimiliki perusahaan, serta hasil-hasil yang di anggap cukup baik.

Gaughan (1996), mengidentifikasikan rasio-rasio keuangan yang secara signifikan memberikan perbedaan kinerja keuangan perusahaan setelah merger dan akuisisi, yaitu

1. Rasio Profitabilitas (profitability ratio)

Adalah rasio-rasio yang menunjukkan keberhasilan perusahaan dalam menghasilkan keuntungan.

Meliputi antara lain:

- Net Profit Margin (NPM)

Yaitu rasio yang digunakan untuk mengukur tingkat kembalian keuntungan bersih terhadap penjualan bersihnya.

- Return on Asset (ROA) Yaitu rasio yang digunakan untuk mengukur efektivitas perusahaan dalam menghasilkan keuntungan dengan memanfaatkan aktiva yang dimiliki.

2. Rasio Aktivitas (activity ratio)

Adalah rasio-rasio yang dimaksudkan untuk mengukur kemampuan atau efisiensi perusahaan dalam memanfaatkan aktiva yang dimilikinya atau perputaran (turn over) dari aktiva-aktiva tersebut.

Meliputi antara lain: 
- Total Asset Turnover (TATO)

Yaitu rasio yang menunjukkan seberapa efektifnya perusahaan menggunakan total asetnya.

Merger adalah salah satu bentuk absorsi/penyerapan yang dilakukan oleh satu perusahaan terhadap perusahaan yang lain. Jika terjadi merger antara perusahaan $A$ dan perusahaan $B$, maka pada akhirnya hanya akan ada satu perusahaan saja, yaitu perusahaan A atau B. Pada sebagian besar kasus merger, perusahaan yang memilki ukuran yang lebih besar yang dipertahankan hidup dan tetap mempertahankan nama dan status hukumnya, sedangkan perusahaan yang berukuran lebih kecil atau perusahaan yang dimerger akan menghentikan aktivitas atau dibubarkan sebagai badan hukum (Lani Dharmasetya dan Vonny Sulaimin, 2009: 10)

Bentuk lain dari penyatuan perusahaan adalah pengambilalihan perusahaan, yang sering disebut dengan akuisisi. Pada akuisisi, masing-masing perusahaan, baik perusahaan yang mengambil alih maupun perusahaan yang diambil alih tetap mempertahankan aktivitasnya, identitasnya, dan kedudukannya sebagai perusahaan yang mandiri. Praktik akuisisi melahirkan hubungan induk perusahaan (perusahaan yang mengambil alih) dan anak perusahaan (perusahaan yang diambil alih) (Lani Dharmasetya dan Vonny Sulaimin, 2009:11)

Berdasarkan hasil dari beberapa penelitian diatas maka hipotesis yang dapat diajukan sebagai jawaban sementara terhadap permasalahan penelitian ini adalah :

$\mathrm{H} 1$ : Terdapat praktik manajemen laba yang dilakukan perusahaan pengakuisisi dengan cara menaikkan nilai akrual (income increasing accrual) sebelum merger dan akuisisi.

H2 : Terdapat perbedaan kinerja keuangan yang di ukur dengan total asset turnover, net profit margin, dan return on asset sebelum dan setelah merger dan akuisisi.

\section{METODE PENELITIAN}

\section{Populasi dan Sampel}

Objek penelitian ini adalah perusahaan yang melakukan merger dan akuisisi. Dalam penelitian ini pengambilan sampel yang dilakukan secara non probability sampling, yaitu dengan pendekatan purposive sampling dengan kriteria sebagai berikut. 
(1) Perusahaan publik yang terdaftar di Bursa Efek Indonesia dan melakukan merger dan akuisisi antara tahun 2008 sampai dengan tahun 2009.

(2) Perusahaan termasuk industri manufaktur dan industri lain selain kelompok perusahaan yang bergerak di bidang asuransi dan industri finance atau perusahaan perbankan dan lembaga keuangan lainnya.

(3) Perusahaan memiliki tanggal merger dan akuisisi yang jelas.

(4) Menerbitkan laporan keuangan auditan secara lengkap selama satu tahun sebelum merger dan akuisisi serta setelah merger dan akuisisi dengan periode berakhir per 31 Desember.

\section{Definisi Operasional}

Definisi operasional merupakan petunjuk tentang bagaimana suatu variabel di ukur, sehingga peneliti dapat mengetahui baik atau buruk pengukuran tersebut. Adapun definisi operasional ini kemudian diuraikan menjadi indikator empiris dalam penelitian. Manajemen laba dalam penelitian ini diukur dengan proxy discretionary accruals (DA) yang menggunakan model Modified Jones (Jones Modifikasi) yang dikembangkan oleh Dechow (1995). Model ini dipilih karena dapat mendeteksi manajemen laba lebih baik dibandingkan dengan model-model lainnya (I Putu Andyana Usadha dan Gerianta Wirawan Yasa,2008).

Model penghitungan manajemen laba adalah sebagai berikut :

$$
\frac{T A_{\text {it }}}{A_{\mathrm{it}-1}}=\alpha_{\mathrm{i}}\left(\frac{1}{A_{\mathrm{it}-1}}\right)+\beta_{1 \mathrm{i}}\left(\frac{\Delta R E V_{\mathrm{it}}-\triangle R E C_{\mathrm{it}}}{A_{\mathrm{it}-1}}\right)+\beta_{2 \mathrm{i}}\left(\frac{P P E_{\mathrm{it}}}{A_{\mathrm{it}-1}}\right)+\epsilon_{\mathrm{it}}
$$

Total akrual untuk periode t dinyatakan dalam persamaan :

$$
T A_{\text {it }}=N I_{\text {it }}-O C F_{\text {it }}
$$

Keterangan :

$T A_{i t} \quad=$ Total Accruals perusahaan i pada tahunt 
$\triangle R E V_{\text {it }}=$ Pendapatan bersih perusahaan i pada tahun ke t dikurangi pendapatan bersih pada tahun $\mathrm{t}-1$

$\triangle R E C_{\tilde{B}}=$ Piutang bersih perusahaan i pada tahun t dikurangi piutang bersih pada tahun $\mathrm{t}-1$

$P P E_{\overline{\mathrm{N}}} \quad=$ Aktiva tetap (gross) perusahaan $\mathrm{i}$ pada tahun $\mathrm{t}$

$A_{i t-1}=$ Total assets (total aktiva) perusahaan i pada tahun $\mathrm{t}-1$

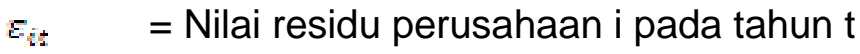

$W_{\text {int }}=$ Laba bersih (Net Income) perusahaan i pada tahun $\mathrm{t}$

$O C F_{1:}=$ Arus kas (Operating Cash Flow) perusahaan $\mathrm{t}$ pada tahun $\mathrm{t}$

Dari persamaan diatas Non Discreationary Accruals (NDA) dapat dihitung dengan memasukkan kembali kefisien a dalam persamaan :

$$
N D A_{\text {it }}=\alpha_{\mathrm{i}}\left(\frac{1}{A_{\text {it }-1}}\right)+\beta_{\text {ii }}\left(\frac{\Delta R E V_{\text {it }}-\Delta R E C_{\text {it }}}{A_{\text {it }-1}}\right)+\beta_{\text {ii }}\left(\frac{P P E_{\text {it }}}{A_{\text {it }-1}}\right)
$$

Setelah melakukan regresi model di atas, Dicretionary Accruals yang dilakukan oleh setiap perusahaan dapat dihitung dengan persamaan sebagai berikut :

$$
\frac{D A_{\text {it }}}{A_{\text {it }-1}}=\frac{T A_{\text {it }}}{A_{\text {it }-1}}-\left[\alpha_{\text {i }}\left(\frac{1_{\text {i }}}{A_{\text {it }-1}}\right)+\beta_{\text {ii }}\left(\frac{\Delta R E V_{\text {it }}-\Delta R E C_{\text {it }}}{A_{\text {it }-1}}\right)+\beta_{\text {ii }}\left(\frac{P P E_{\text {it }}}{A_{\text {it }-1}}\right)\right]
$$

Atau

$D A_{i t}=T A_{i t}-N D A_{i t}$

Keterangan :

$\mathrm{WDA}_{\tilde{\mathrm{N}}}=$ Non Discreationary Accruals perusahaan $\mathrm{i}$ pada tahun $\mathrm{t}$ $D A_{\tilde{\text { }}} \quad=$ Discreationary Accruals i pada tahun $\mathrm{t}$ 
Secara empiris, nilai Discretionary Accruals dapat bernilai nol, positif, atau negatif. Nilai nol menunjukkan manajemen laba dilakukan dengan pola perataan laba (income smoothing). Sedangkan nilai positif menunjukkan adanya manajemen laba dengan pola peningkatan laba (income increasing) dan nilai negatif menunjukkan manajemen laba dengan pola penurunan laba (income decreasing) (Sulistyanto, 2008)

Kinerja keuangan didefinisikan sebagai prestasi manajemen keuangan untuk mencapai tujuan perusahaan yaitu menghasilkan keuntungan dan meningkatkan nilai perusahaan. Kinerja keuangan dalam penelitian ini di ukur dengan menggunakan rasio aktivitas dan profitabilitas.

1. Rasio Aktivitas menunjukkan kemampuan dana yang tertanam dalam keseluruhan aktiva berputar dalam suatu periode tertentu atau kemampuan modal yang di investasikan untuk menghasilkan revenue. Pengukuran rasio aktivitas disini menggunakan total asset turnover.

Total Asset Turnover $($ TATO $)=\frac{\text { Penjualannetc }}{\text { Jumlah Aktiva }}$

2. Rasio Profitabilitas mengukur seberapa besar kemampuan perusahaan memperoleh laba baik dalam hubungannya dengan penjualan, aset maupun laba bagi modal sendiri. Pengukuran rasio profitabilitas ini menggunakan net profit margin dan return on asset.

Net Provit Margin $(N P M)=\frac{\text { Keuntungan neto sesudah pajak }}{\text { Penjualan neto }}$

Return on $A \operatorname{sset}(R O A)=\frac{\text { EBNT }}{\text { Jum?a/2ARtīu }}$

\section{Metode Pengumpulan Data}

Metode pengumpulan data yang digunakan dalam penelitian ini adalah dengan metode studi pustaka yang dilakukan dalam rangka mengumpulkan teori-teori atau literatur-literatur yang dapat dipergunakan sebagai landasan yang berhubungan dengan masalah yang sedang teliti. Berkaitan dengan data-data yang digunakan dalam penelitian ini, data-data yang dibutuhkan terdiri dari data sekunder. Data mengenai harga saham diperoleh dari Indonesian Capital Market Directory (ICMD), idx statistic, dan Bursa Efek Indonesia (BEl) di pojok BEl. 


\section{Metode Analisis Data}

Analisis rasio keuangan digunakan untuk menganalisis keputusan merger dan akuisisi terhadap kondisi keuangan rasio-rasio tersebut dibandingkan dengan rasio sebelum merger dan akuisisi. Langkah pertama yang dilakukan adalah menghitung masing-masing rasio keuangan yang sudah ditetapkan sebagai variabel penelitian. Hasil perhitungan rasio-rasio ini selanjutnya digunakan sebagai data dalam pengujian statistik.

\section{Pengujian Hipotesis}

Uji independent sample t-test digunakan untuk menguji hipotesis 1, yakni untuk mengetahui apakah pihak manajemen melakukan tindakan manajemen laba dengan cara menaikkan atau menurunkan nilai akrual perusahaan pada periode sebelum pelaksanaan merger dan akuisisi.

Uji paired sample t-test digunakan untuk menguji hipotesis 2, yakni untuk membuktikan apakah terdapat perbedaan kinerja keuangan jika dilihat dari segi rasio aktivitas yang di ukur dengan total asset turnover dan rasio profitabilitas yang di ukur dengan net provit margin dan return on asset pada periode sebelum dan setelah pelaksanaan merger dan akuisisi. 


\section{KESIMPULAN}

Berdasarkan hasil analisis dan pembahasan yang telah disampaikan sebelumnya, simpulan yang dapat diambil dalam penelitian ini, adalah:

1. Penelitian ini membuktikan bahwa tidak terdapat praktik manajemen laba yang dilakukan perusahaan pengakuisisi dengan cara menaikkan nilai akrual (income increasing accruals) sebelum merger dan akuisisi.

2. Penelitian ini membuktikan bahwa kinerja keuangan yang diproksikan dengan total asset turnover (TATO), net provit margin (NPM) dan return on asset (ROA) mengalami perubahan yang berbeda-beda baik sebelum maupun sesudah merger dan akuisisi. TATO mengalami kenaikan sesudah merger dan akuisisi dibandingkan sebelum merger dan akuisisi, sedangkan NPM dan ROA mengalami penurunan sesudah merger dan akuisisi.

\section{Keterbatasan}

Penelitian ini memiliki keterbatasan. Beberapa hal yang menjadi keterbatasan dalam penelitian ini, adalah:

1. Penelitian ini hanya menggunakan sampel dalam jumlah yang terbatas, masih jarangnya perusahaan yang melakukan aktivitas merger dan akuisisi pada pasar modal Indonesia menyebabkan sulitnya diperoleh jumlah sampel yang representative.

2. Penelitian ini tidak mampu membuktikan adanya manajemen laba dan perbedaan kinerja perusahaan periode sebelum dan sesudah merger dan akuisisi. 


\section{DAFTAR PUSTAKA}

Adnyana Usadha, I Putu dan Gerianta Wirawan Yasa. 2008. "Analisis manajemen Laba dan Kinerja Perusahaan Pengakuisisi sebelum dan sesudah Merger dan Akuisisi di Bursa Efek Indonesia”. Jurnal Fakultas Ekonomi, Universitas Udayana, Denpasar

Belkaoui, Ahmed Riahi. 2004. Teori Akuntansi. Buku 1, Jakarta: Salemba Empat

Dharmasetya MM.,BKP, Lani dan Vonny Sulaimin, Msi.,CPA, 2009,Merger dan Akuisisi tinjauan dari sudut Akuntansi dan Perpajakan, Jakarta, PT Elex Media Komputindo KOMPAS GRAMEDIA

Daga, R. (2017). STRATEGI MENINGKATKAN KEPUASAN NASABAH TABUNGAN PADA PT. BANK PERKREDITAN RAKYAT HASA MITRA CABANG MAKASSAR. AKMEN Jurnal IImiah, 14(3).

Daga, R. (2021). ANALISIS TINGKAT KEPUASAN NASABAH TERHADAP SISTEM ANTRIAN PADA PT. BANK RAKYAT INDONESIA (Persero) Tbk. UNIT BTP TAMALANREA. 
Foster, George. 1986. Financial Statement Analysis. New Jersey : Prentice Hall Englewood

Ghozali, Imam, 2005. Analisis Multivariate dengan program SPSS, Edisi 3, Badan penerbit Universitas Diponegoro, Semarang

Hadiningsih, Murni. 2007. "Analisis Dampak Jangka Panjang Merger dan Akuisisi terhadap Kinerja Keuangan Perusahaan Pengakuisisi dan Perusahaan Diakuisisi di Bursa Efek Jakarta (BEJ)". Skripsi, Sarjana Jurusan Manajemen Keuangan, Fakultas Ekonomi, Universitas Islam Indonesia, Yogyakarta

Halim, Julia., Camel maiden dan Rudolf Lumban Tobing. 2005. "'Pengaruh Manajemen Laba pada Tingkat Pengungkapan Laporan Keuangan pada Perusahaan Manufaktur yang Termasuk dalam Indeks LQ-45'. Disampaikan pada Simposium Nasional Akuntansi (SNA) VIII Solo

Hastutik, Anita Widi. 2006. "Analisis Manajemen Laba (Earnings Management) oleh Perusahaan Pengakuisisi Sebelum dan Sesudah Merger dan Akuisisi di Indonesia". Skripsi, Sarjana Jurusan Akuntansi Fakultas Ekonomi, Universitas Brawijaya, Malang

Hitt, A Michael. 2002. Merger dan Akuisisi: Paduan Meraih Laba Bagi Para Pemegang Saham. Edisi 1, PT Raja Grafindo Persada, Jakarta

Husnan, Suad. 2001. Manajemen Keuangan: Teori dan Penerapan. Edisi ke-3. Yogyakarta: BPFE

Ikatan Akuntan Indonesia. 2007. Standar Akuntansi Keuangan. Jakarta: Salemba Empat

Indriyani Sijabat, Sarah. 2009. "Analisis Kinerja Keuangan Sebelum dan Sesudah Merger dan Akuisisi Pada Perusahaan yang Terdaftar di Bursa Efek Indonesia”. Jurnal Akuntansi, Fakultas Ekonomi, Universitas Sumatera Utara 
Institute for Economic and Financial Research, 2008-2009, Indonesian Capital Market Directory, Jakarta

Kusuma, Hadri dan Wigna Ayu Udiana Sari. 2003. "'Manajemen Laba oleh Perusahaan

Pengakuisisi Sebelum dan Sesudah Merger dan Akuisisi di Indonesia”. Jurnal Akuntansi dan Auditing Indonesia Vol. 7 No. 1

Payamta, dan Sektiawan, 2004. "Analisis Pengaruh Merger dan Akuisisi Kinerja Perusahaan Publik di Indonesia". Jurnal Riset Akuntansi Indonesia, Vol. 7 No 3

Payamta, 2000. "Analisis Pengaruh Keputusan Merger dan Akuisisi terhadap Perubahan Kinerja Perusahaan Publik di Indonesia". Disampaikan pada Simposium Nasional Akuntansi Indonesia IV

Saiful, 2003. "Abnormal Return Perusahaan Target dan Industri Sejenis Seputar Sektor Pengumuman Merger dan Akuisisi”. Jurnal Riset Ekonomi dan Manajemen, Vol.3 No.1

Susanta, I Gede Adi. 2006. 'Manajemen Laba Menjelang IPO dan Pengaruhnya terhadap Return Saham pada Perusahaan yang Terdaftar di Bursa Efek Jakarta". Skripsi, Sarjana jurusan Akuntansi, Fakultas Ekonomi, Universitas Udayana, Denpasar 
Widyaningdyah, Agnes Utari. 2001. "Analisis Faktor-faktor yang Berpengaruh terhadap Earnings Management pada Perusahaan Go Public di Indonesia". Jurnal Akuntansi dan Keuangan 3 (2). Hal: 89-101

www.idx.go.id 